\title{
Pelaksanaan Program Bina Diri bagi Siswa Berkebutuhan Khusus di Sekolah Inklusi
}

\author{
Lina Mei Wulandari,Sinta Yuni Susilawati,Usep Kustiawan
}

\author{
Universitas Negeri Malang \\ E-mail: linameiw@gmail.com
}

\begin{abstract}
Abstrak: Banyak sekolah inklusi hanya memperhatikan layanan akademik siswa berkebutuhan khusus saja, padahal mereka memiliki kebutuhan dasar yang tidak mampu dipenuhi karena keterbatasan yang dimiliki.Salah satu program yang bisa membantu dalam pemenuhan kebutuhan dasar adalah bina diri. Pada tingkat SMP, program bina diri yang dapat diberikan yaitu memasak. Penelitian ini menggunakan metode penelitian kualitatif studi kasus.Hasil penelitian menunjukkan bahwa pelaksanaan program bina diri memasak di SMP Negeri 4 Sidoarjo berjalan dengan baik dan sesuai teori. Kendala meliputi siswa lupa jadwal pull out memasak, mood siswa tidak menentu, dan jadwal bina diri memasak terbentur kegiatan sekolah. Upaya untuk mengatasi kendala yaitu mengingatkan siswa dan orangtua sehari sebelumnya,membujuk siswa sesuai karakternya, dan mengundur pelaksanaan atau merubah jumlah kelompok. Dampak meliputi kemandirian, melatih motorik halus,mengembangkan jiwa kewirausahaan, dan memahami penggunaan uang.
\end{abstract}

Kata Kunci: Bina diri; memasak; Inklusi

\begin{abstract}
Many inclusive schools only pay attention to academic services of special needs students, even though they have basic needs that are not able to be fulfilled because of their limitations. One program can help is self development. At the junior high school level, self development program can be given is cooking. The method in this study was a case study of qualitative research. Results of the research showed that implementation of self cooking development program at SMP Negeri 4 Sidoarjo went well and in accordance with the theory. Obstacles include students forgetting the pull out cooking schedule, uncertain mood of students, and the schedule collided with school activities. Efforts to overcome obstacles are reminding students and parents the day before, persuading students appropriate their character, postponing the implementation or changing groups. Impacts include independence, fine motor training, developing an entrepreneurial spirit, and understanding the use of money.
\end{abstract}

Keyword: Self-development;Cooking;Inclusive

Mudjito, dkk (2012) memaparkan bahwa anak berkebutuhan khusus adalah anak yang memiliki karakteristik khusus baik secara fisik, mental, atau emosi dibandingkan dengan anak pada umumnya, yang kemudian dikategorikan kedalam tunanetra, tunarungu, tunadaksa, tunagrahita, autis, anak berbakat, kesulitan belajar, gangguan perilaku, dan anakanak dengan gangguan kesehatan. Salah satu bentuk layanan pendidikan bagi anak berkebutuhan khusus adalah pendidikan inklusi. Pendidikan inklusi adalah sistem pendidikan yang memberikan kesempatan bagi abk untuk bersekolah bersama anak reguler sesuai dengan kebutuhan dan kemampuannya. Namun pada kenyataannya, banyak sekolah inklusi yang cenderung hanya memperhatikan kemampuan akademik anak berkebutuhan khusus saja. Wahyuno,dkk (2014) berpendapat bahwa sekolah inklusif selama ini hanya menggunakan kurikulum sekolah reguler yang dimodifikasi sesuai kemampuan anak berkebutuhan khusus, tidak ada kurikulum tambahan yang sesuai dengan kebutuhan anak berkebutuhan khusus padahal di sekolah inklusif masih diperlukan kurikulum tambahan (kurikulum khusus) yaitu kurikulum yang berisi tentang materi maupun latihan yang menjadi kebutuhan anak berkebutuhan khusus yang tidak ada dalam kurikulum reguler.

Efendi (2006) menjelaskan bahwa anak berkebutuhan khusus sebagaimana individu lainnya mempunyai kebutuhan dasaryang harus dipenuhinamun kebutuhan tersebut sering kali gagal untuk dipenuhi oleh anak berkebutuhan khusus karena keterbatasan yang dimilikinya. Maka, sekolah yang menerima anak berkebutuhan khusus hendaknya berupaya menyediakan layanan pendidikan untuk melatih anak bekrebutuhan khusus dapat mengoptimalkan diri untuk memenuhi kebutuhan dasarnya secara mandiri. Salah satunya dengan penyelenggaraan program bina diri. Menurut Sudarsini (2017) program bina diri yaitu program yang dilatihkan kepada anak berkebutuhan khusus sesuai dengan karaketristiknya menyangkut kebutuhan-kebutuhan hidup secara mandiri sehingga bisa dijadikan bekal untuk beradaptasi di lingkungan 
masyarakat. Melalui pengadaan program bina diri diharapkan siswa berkebutuhan khusus mendapatkan bekal untuk mampu melaksanakan tugas sesuai usia perkembangannya meskipun berada di sekolah inklusi. Garnida (2016) menyebutkan pembelajaran bina diri harus dilaksanakan dengan memperhatikan prinsip-prinsip umum antara lain (a)berdasarkan hasil asesmen, (b) memperhatikan unsur keselamatan, (c) memperhatikan unsur-unsur kehati-hatian, (d) mempertimbangkan kemandirian siswa berkebutuhan khusus, (e) meningkatkan kepercayaan diri siswa berkebutuhan khusus, (f) memperhatikan sosial dan budaya tempat tinggal siswa, dan (g) disesuaikan dengan usia siswa. Program bina diri yang diterapkan pada jenjang sekolah dasar tentu saja berebeda dengan kegiatan sekolah menengah pertama maupun menengah atas. Pada tingkat SMP pengembangan bina diri tidak hanya membelajarkan anak bagaimana cara makan saja tetapi cara mengolah makanan untuk dimakan juga. Iswari (2007) menyebutkan kecakapan hidup dalam kehidupan sehari-hari bagi anak berkebutuhan khusus ditingkat SMP antara lain: (a) mengelola dan mengatur keuangan sendiri; (b) mengelola dan mengatur kebutuhan rumah tangga; (c) mengatur kebutuhan sendiri; (d) kesadaran akan rasa aman; (e) memasak dan menghidangkan makanan; (f) membeli dan merawat pakaian; (g) menunjukkan sebagai warga negara yang bertanggung jawab; dan (h) memahami kehidupan di tengah masyarakat.

Berdasarkan studi pendahuluan pada februari 2018 di SMP Negeri 4 Sidoarjo, diketahui bahwa ada pengadaan program bina diri bagi siswa berkebutuhan khusus antara lain (a) mencuci dan menyetrika baju; (b) menggosok gigi, merapikan baju dan rambut; (c) memasak; (d) menjahit; dan (3) berkebun. Dari beberapa bina diri yang daiajarkan bagi anak berkebutuhan khusus di SMP Negeri 4 Sidoarjo, yang menarik untuk diteliti adalah pelaksanaan bina diri memasak. Lubis (2013) menjelaskan memasak merupakan proses pemberian panas terhadap bahan mentah sampai menjadi mantang sehingga makanan aman dimakan, memiliki rasa dan aroma yang sedap, dan memiliki kandungan gizi seimbang jika adanya kombinasi bahan makanan lain. Memasak merupakan pembelajaran yang paling ditunggu-tunggu oleh siswa berkebutuhan khusus di SMP Negeri 4 Sidoarjo,hal tersebut dibuktikan dari seringnya siswa bertanya kepada GPK tentang kapan pelaksanaan memasak. Pembelajaran memasak yang dilaksanakan memiliki banyak dampak positif bagi anak berkebutuhan khusus karena mencakup banyak ruang linkup bina diri antara lain menolong diri, komunikasi, sosialisasi dan adaptasi, dan juga ketrampilan hidup sehari-hari.

\section{METODE}

Penelitian ini dilaksanakan menggunakan pendekatan kualitatif dengan pendekatan studi kasus.
Teknik pengumpulan data dalam peenlitian kualitatif yaitu obserevasi, wawancara, dan dokumentasi. Observasi yang digunakan untuk mengetahui kondisi lapangan yang diteliti, peneliti menggunakan observasi partisipatif dimana peneliti terlibat dengan kegiatan sehrai-hari subjek yang sedang atau yang digunakan sebaagi sumber data penelitian. Wawancara yang digunakan dalam penelitian ini menggunakan wawancara mendalam (in-depth interview) dengan jenis wawancara semi terstruktur. Sedangkan dokumentasi digunakan sebagai pelengkap dan pembuktian dari proses wawancara dan observasi yang diperoleh dari hasil pengumpulan data agar data dapat dipercaya (akurat).

Teknik analisis data yang digunakan adalah reduksi data, penyajian data, dan penarikan kesimpulan/ verifikasi. Sumber data pada penelitian kualitatif diperoleh berdasarkan informan dan rekomendasi informan sehingga diperoleh sumber data untuk diwawancarai, diobservasi, dan didokumentasikan. Sumber data didapatkan dari hasil wawamcara dengan koordinator inklusi, waka sarana dan prasarana, tim gpk, dan juga wali murid siswa berkebutuhan khusus SMP Negeri 4 Sidoarjo.

\section{HASIL DAN PEMBAHASAN}

\section{Hasil}

Program bina diri memasak meruapakan salah satu layanan pendidikan non akademik yang dilaksanakan bagi anak berkebutuhan khusus di SMP Negeri 4 Sidoarjo. Pelaksanaan program bina diri memasak terdiri dari beberapa tahap yaitu perencanaan, pelaksanaan, dan evaluasi. Perencanaan program yang ditetapkan melalui rapat koordinasi 1 dan II dengan mempertimbangkan kemampuan anak berkebutuhan khusus, potensi guru pembimbing khusus, dan potensi sekolah inklusi. Setelah mendapat persetujuan,maka guru pembimbing khusus akan menyusun rancangan pelaksanaan pembelajaran (RPP). Pelaksanaan pembelajaran memasak dibagi menjadi dua pertemuan. Pertemuan pertama dilaksanakan pembelajaran penyampaian materi sedangkan pertemuan kedua yaitu praktik memasak. Evaluasi terdiri dari dua jenis yaitu evaluasi program dan evaluasi hasil belajar.

Kendala dalam proses pelaksanaan program bina diri memasak antara lain siswa lupa jadwal pull out, suasana hati yang tidak menentu, dan jadwal pelaksanaan terbentur dengan kegiatan sekolah. Kendala tersebut dapat teratasi dengan beberapa upaya yang dilakukan oleh GPK yang berkoordinasi dengan koordinator inklusi dan kepala sekolah yaitu: (a) mengingatkan sehari sebelum pelaksanaan atau gpk menjemput satu persatu siswa berkebutuhan khusus di kelas reguler; (b) membujuk dan memotivasi siswa sesuai dengan karakter siswa berkebutuhan khusus; dan (c) pelaksanaan memasak diundur atau merubah 
jumlah kelompok. Dampak dari pelaksanaan program bina diri memasak yaitu kemandirian siswa untuk bisa memasak sendiri, meningkatkan kepercayaan diri, meningkatkan kerjasama antar siswa, melatih kemampuan motorik, dan juga meningkatkan pemahaman tentang penggunaan uang.

\section{Pembahasan}

\section{Pelaksanaan program bina diri memasak}

Proses pelaksanaan program bina diri di SMP Negeri 4 Sidoarjo memiliki tiga tahap. Tahap pertama yaitu perencanaan. Tahap perencanaan program bina diri memasak bagi anak berkebutuhan khusus di SMP Negeri 4 Sidoarjo dilakukan dengan cara tim guru pembimbing khusus (GPK) menentukan dan menyusun program bina diri memasak berdasarkan kebutuhan dan kemampuan siswa berkebutuhan khusus yang diperoleh dari hasil identifikasi dan assesmet yang telah dilakukan, potensi guru pembing khusus, dan juga potensi sekolah penyelenggara inklusi. Selanjutnya akan diadakan rapat koordinasi I antara tim gpk, koordinator inklusi, kepala sekolah, dan komiite sekolah. Rapat koordinasi II yang dihadiri kepala sekolah dan/koordinator inklusi, gpk, dan orangtua siswa berkebutuhan khusus, gpk memaparkan program bina diri memasak kepada orangtua siswa berkebutuhan khusus. Setelah mendapat persetujuan tim gpk akan menyusun rancangan pelaksanaan pembelajaran. Pernyataan diatas sesuai dengan penelitian Persada,dkk (2017) menjelaskan bahwa keterlibatan orangtua di sekolah anaknya tidak hanya sekedar ikut memberikan partisipasi nominal, tetapi juga telah mampu merumuskan program dan kegiatan tersebut dengan penuh tanggung jawab .

Kurikulum program bina diri memasak yang digunakan merupakan kurikulum tambahan yang berorientasi kecakapan hidup yang disesuaikan dengan kemampuan masing-masing siswa berkebutuhan khusus dengan format K13 yang terdiir dari pendahuluan, kegiatan inti, dan penutup. Pendidikan kecakapan hidup diberikan agar anak berkebutuhan khusus dengan berani memenuhi kebutuhan hidupnya secara mandiri ditengah ketebatasan yang dimilikinya. Hal ini sesuai dengan pendapat Efendi (2009) bahwa pendidikan kecakapan hidup adalah kecakapanyang secara praktis diajarkan agar seseorang berani menghadapi problema hidup dan kehidupan dengan wajar tanpa merasa tertekan sehingga secara aktif dan proaktif menemukan solusi dan pada akhirnya mampu mengatasinya.

Materi memasak bersumber dari internet atau buku resep masakan yang disesuaikan dengan kemampuan siswa berkebutuhan khusus dan guru pembimbing khusus. Materi disampaikan dengan metode yang bervariasi antara lain metode ceramah, metode tanya jawab, metode penugasan, dan metode demonstrasi. Metode yang bervariasi digunakan sesuai dengan kemampuan anak berkebutuhan khusus agar mereka memahami materi yang disampaikan. Hal ini sesuai dengan pendapat Zain,dkk (2014) menjelaskan bahwa ketepatan penggunaan metode pembelajaran yag sesuai dengan karakteristik peserta didik sanat berpengaruh terhadap peningkatkan kemampuan belajar peserta didik.

Media yang digunakan adalah gambar dan benda asli. Media digunakaan untuk mengenalkan alat,bahan, dan langkah-langkah memasak sederhana materi memasak yang akan dipraktikkan. Penggunaan media untuk menunjang kemudahan pemahanan anak berkebutuhan khusus terhadap pembelajaran memasak sehinga hasil belajar memuaskan. Hal ini sesuai dengan penelitian Sari,dkk (2014) menjelaskan bahwa penggunaan media dapat memberikan pengaruh positif yaitu meningkatkan pemahaman terhadap materi yang disampaikan sehingga hasil belajar siswa meningkat juga.

Pembelajaran bina diri memasak dilaksanakan secara berkelompok heterogen dari kelas VII-IX yang dibagi berdasarkan kemampuan siswa berkebutuhan khusus. Saat pelaksanaan, secara bersama-sama siswa berkebutuhan khusus dan gpk mempersiapkan penunjang pembelajaran memasak dan setiap siswa melaksanakan kegiatan memasak sesuai dengan tugas yang telah dibagikan. Hal ini sesuai dengan pendapat Sutirman (2014) model pembelajaran kooperatif merupakan rangkaian kegiatan belajar secara berkelompok dimana harus ada aturan dan pembagian tugas yang jelas untuk mencapai tujuan tertentu.

Program bina diri memasak dilaksanakan dalam dua pertemuan pembelajaran. Pada pertemuan pertama dilaksanakan penyampaian materi resep masakan yang akan dipraktekkan. Materi tersebut berisi tentang pengenalan bahan, pengenalan peralatan memasak, dan juga penjelasan sederhana langkah-langkah memasak sesuai dengan kemampuan siswa berkebutuhan khusus. Guru pembimbing khusus juga memberikan tindak lanjut untuk menulis resep masakan di buku tugas. Penyampaian materi dilakukan untuk memberikan pengetahuan awal bagi siswa berkebutuhan khusus sehingga tidak kebingungan ketika praktik. Hal ini sesuai dengan pernyataan Depdiknas (2006) bahwa penyampaian materi jenis prosedur bertujuan agar siswa dapat memahami komponen dan langkahlangkah mengerjakan sesuatu secara berurutan sebelum dilaksanakan praktek.

Pada pertemuan kedua yaitu pembelajaran praktek, siswa berkebutuhan khusus diajak untuk berbelanja bahan masakan di pasar dengan cara setiap siswa berkebutuhan khusus diberikan catatan bahan yang akan dibeli. Tahap selanjutnya siswa dan guru pembimbing khusus bersama-sama menyiapkan peralatan memasak seperti kompor, wajan, pisau, telenan,dan peralatan lain sesuai dengan kebutuhan 
memasak. Lalu mereka mencuci tangan, memakai celemek, dan memakai sarung tangan. Sebelum memasak, siswa diajak untuk mereview pengetahuan tentang alat dan bahan yang telah diajarkan dengan cara mengidentifikasinya. Melalui proses mereview dengan identifikasi diharapkan anak berusaha mengingat kembali materi pembelajaran yang disampaikan sebelumnya sehingga pemahamannya tentang materi tersebut menguat. Hal ini sesuai dengan pendapat Mansur (2015) bahwa dalam hukum belajar latihan (law of exercise), makin sering suatu materi diulang maka akan semakin dikuasi materi tersebut.

Pada proses memasak, guru pembimbing khusus memberikan tugas kepada masing-masing siswa sesuai dengan kemampuannya. Setiap tugas yang diberikan, gpk akan mendemonstrasikan terlebih dahulu lalu diteruskan siswa secara mandiri namun tetap masih ada arahan secara verbal maupun tindakan. Masakan yang sudah matang didinginkan lalu dikemas. Proses pembelajaran yang terakhir adalah berjualan yang dilaksanaan oleh siswa berkebutuhan khusus kepada guru reguler.

Sarana dan prasarana penunjang program bina diri memasak yang disediakan sekolah cukup memadai. Peralatan memasak yang dimiliki cukup lengkap sehingga proses pembelajaran memasak berjalan dengan baik. Hal ini sesuai dengan peneltian Fadhilah (2014) menjelaskan bahwa sarana dan prasarana yang memadai dan pemanfaatan yang tepat memberikan dorongan terhadap aktivitas belajar yang dapat menghasilkan prestasi belajar sesuai dengan tujuan yang diharapkan.

Evaluasi pelaksanaan programbina diri memasak terdiri dari evaluasi program dan evaluasi hasil belajar. Proses evaluasi program bina diri memasak dilakukan melalui monitoring dan supervisi yang dilakukan oleh kepala sekolah dalam sebuah rapat dengan gpk dan koordinator inklusi diketahui oleh wali murid setiap satu semester sekali dan satu tahun sekali. Widyoko (2014) menjelaskan evaluasi program pendidikan dilakukan secara sistematis dan berkelanjutan untuk mengumpulkan,mendeskripsikan,menginterprestasi kan, dan menyajikan informasi tentang pelaksanaan program yang telah dilaksanakan untuk dapat dijadikan dasar membuat keputusan, menyusun kebijakan maupun menyusun program selanjutnya.

Sedangkan evaluasi hasil belajar siswa dilakukan oleh guru pembimbing khusus melalui pengamatan dan tes lisan selama proses pembelajaran memasak berlangsung. Evaluasi tersebut dilakukan agar mengetahui perkembangan setiap anak berkebutuhan khusus dalam pelaksanaan memasak, sehingga mengetahui kemampuan anak. Hal ini sesuai dengan pendapat Sudjana (2013) bahwa tujuan evaluasi hasil belajar adalah untuk mendeskripsikan kecakapan belajar para siswa untuk mengetahui kelebihan dan kekurangannya dalam berbagai bidang studi yang ditempuhnya sehingga dapat ditentukan tindak lanjut untuk memperbaiki atau meningkatnya. Evaluasi hasil belajar siswa dilakukan secara deskriptif dalam setiap tahapan belajar.

\section{Kendala pelaksanaan program bina diri memasak \\ Pelaksanaan program bina diri memasak bagi} siswa berkebutuhan khusus tentu menemui kendala apalagi dilaksanakan di sekolah inklusi dimana lingkungannya mayoritas reguler. Kendala-kendala yang selama ini dihadapi adalah: a) siswa lupa adanya jadwal pull out memasak, kendala ini biasanya muncul ketika akan dilaksanakan praktek memasak yang dimulai sejak pukul 07.00 WIB; b) suasana hati hati yang tidak menentu misalnya tiba-tiba tidak mau terlibat, bercanda dengan teman,bahkan salah satu siswa autis jika sudah duduk sangat susah untuk bergerak; dan c) jadwal pelaksanaan terbentur dengan kegiatan sekolah, program bina diri memasak yang sudah dirancang terkadang dalam pelaksanaan akan terbentur kegiatan reguler sekolah seperti pulang pagi, try out kelas 9, ataupun pensi.

\section{Upaya mengatasi kendala pelaksanaan program bina diri memasak}

Kendala-kendala yang terjadi dapat diatasi karena adanya kesadaran karena dan komitmen dari semua masyarakat sekolah untuk mendukung lingkungan belajar yang inklusif. Upaya untuk mengatasi kendala siswa lupa adanya jadwal pull out memasak khususnya ketika praktek memasak yang dimulai sejak pagi adalah 1) mengingatkan kepada siswa yang bersangkutan dan mengirim pesan kepada wali murid sehari sebelumnya untuk mengingatkan anaknya bahwa ada pembelajaran memasak atau 2) guru pembimbing khusus akan menjemput satu persatu siswa berkebutuhan khusus di kelas reguler.

Selanjutnya upaya untuk mengatasi suasana hati siswa berkebutuhan khusus yang tidak menentu dengan cara membujuk siswa berkebutuhan khusus sesuai dengan karakteristiknya misalnya membujuk siswa tunagrahita dengan halus sedangkan untuk siswa autis sedikit lebih tegas. Selain itu siswa yang memang jarang terlibat memasak, guru pembimbing khusus akan memberikan tugas untuk berjualan.

Terkait jadwal pelaksanaan yang terbentur kegiatan sekolah,guru pembimbing khusus atas sepengetahuan koordinator inklusi dan kepala sekolah akan mengundur pelaksanaan program bina diri memasak atau juga dengan cara merubah jumlah kelompok menjadi lebih sedikit, awalnya 4 kelompok menjadi 3 kelompok dimana anggotanya memiliki kemampuan yang tidak jauh berbeda. 
Dampak pelaksanaan program bina diri memasak

Dampak dari kegiatan memasak yang pertama adalah kemandirian, hal tersebut terbukti ketika ssiwa dapat memasak untuk diirnya atau membantu menyiapkan makanan untuk anggota keluarga lainnya di rumah. Bahkan siswa tertarik untuk mencoba materi memasak yang sudah diajarkan dipraktekkan di rumah. Hal ini sesuai dengan penjelasan Mechling (2008) menjelaskan bahwa pengajaran ketrampilan fungisonal seperti meamsak dapat meningkatkan kemandirian dan peluang bagi orang berkebutuhan khusus.

Dampak kedua adalah mengembangakan jiwa kewirausahaan. Jiwa kewirausahaan yang dimaksud antara lain keberanian untuk mencoba dan berhadapan dengan orang lain, kreatif, selain itu program bina diri yang dilaksanakn secara berkelompok dapat pula mengembagkan kerjasama antar siswa berkebutuhan khusus untuk bersama-sama menyelesaikan tugas memasak dengan penuh tanggung jawab. Hal ini sesuai dengan hasil peenlitian yang dilakukan Bhakti (2015) menjelaskan kegiatan cooking class dapat meningkatkan jiwa kewirausahaan antara lain: kreativitas, keberanian, kerjasama, dan tanggung jawab.

Aktivitas belanja bahan masakan di pasar tradisional dan menjual hasil masakan dapat melatih anak berkebutuhan khusus untuk belajar memahami dan menalar mata uang. . Dampak tersebut sesuai dengan pendapat Sulistiowati (2014) dalam penelitiannya bahwa praktik jual beli pada anak tunagrahita dapat meningkatkan kemampuan penalaran mata uang. Kemampuan penalaran mata uang yang dimaksudkan yaitu mengenal (menyebutkan,menunjukkan, membedakan) mata uang baik kertas dan logam beserta nominalnya, mampu untuk menghitung banyaknya barang yang dibeli dengan uang yang harus dibayar, mampu untuk memberikan uang kembalian baik dalam bentuk kertas dan logam. Kegiatan memasak juga dapat melatih motorik halus siswa berkebutuhan khusus.hal tersebut sesuai dengan pendapat Muthoharoh (2012) yang menjelaskan motorik halus anak dapat ditingkatkan melalui kegiatan memotong, mengupas,membuat adonan dan mencetak pada kelas memasak.

\section{KESIMPULAN DAN SARAN}

\section{Kesimpulan}

Kesimpulan dalam penelitian ini menunjukkan bahwa pelaksanaan program bina diri memasak dilaksanan melalui tahap: (a) perencanaan program yang disesuikan dengan kemampuan siswa berkebutuhan khusus, potensi guru pembimbing khusus, dan potensi sekolah penyelenggara; (b) program bina diri memasak yang dilaksanakan dalam dua pertemuan pembelajaran yaitu penyampaian materi dan praktik memasak; dan (c) evaluasi yang terdiri dari evaluasi program dan evaluasi hasil belajar. Kendala yang selama ini dihadapi antara lain: a) siswa lupa adanya jadwal pull out memasak; b) suasana hati siswa tidak menentu; dan c) jadwal pelaksanaan bina diri memasak terbentur kegiatan sekolah. Upaya untuk mengatasi kendala antara lain: (a) mengingatkan siswa berkebutuhan khusus dan wali murid satu hari sebelum pembelajaran memasak atau gpk menjemput satu persatu siswa berkebutuhan khusus di kelas reguler; (b) gpk membujuk siswa sesuai dengan karakteristiknya; dan (c) mengundur pelaksanaan atau merubah jumlah kelompok. Dampak yang ditimbulkan yaitu: kemandirian, melatih motorik halus, mengembangkan jiwa kewirausahaan, dan meningkatkan pemahaman mata uang.

\section{Saran}

Berdasarkan kesimpulan di atas, beberapa saran yang dikemukakan dalam penelitian ini antara lain sebagaiberikut:(1)BagiGuru, Guru perlu meningkatkan perhatian dan pengawasan kepada siswa berkebutuhan khusus saat peroses pelaksanaan dan juga hendaknya penyampaian materi dilaksanakan tidak terlalu jauh dari praktek memasak. (2) Bagi lembaga, Sekolah penyelenggara inklusi dapat melakukan kerja sama dengan pihak kantin sekolah agar siswa berkebutuhan khusus dapat menjual hasil masakannya.

\section{DAFTAR RUJUKAN}

Bhakti,Wida. (2015). Upaya Meningkatkan Entrepreneurship Anak Melalui Cooking Class Pada Kelompok B.Jurnal PG-PAUD Trunojoyo, 2(2),105-116 Retrieved From http://journal. trunojoyo.ac.id/pgpaudtrunojoyo/article/ view/2607

Depdiknas. (2006). Pedoman Memilih dan Menyusun Bahan Ajar. Jakarta: Depdiknas

Efendi,M.(2006).Pengantar Psikopedagogik Anak Berkelainan. Jakarta:Bumi Aksara

Fadhilah,N.I.(2014).Peranan Sarana Dan Prasarana Pendidikan Guna Menunjang Hasil Belajar Siswa Di SD Islam Al Syukro Universal.Skripsi tidak diterbitkan.Jakarta:FITK UINSH

Garnida,D.(2016). Modul Guru Pembelajar SLB Tunagrahita Kelompok Kompetensi A. Jakarta: Kementrian Pendidikan dan Kebudayaan; Direktorat Jenderal Guru dan Tenaga Kependidikan; Taman Kanak-Kanak dan Pendidikan Luar Biasa. (Online), (http://tkplb. kemendikbud.go.id),

Iswari,Mega.(2017).Kecakapan Hidup Bagi Anak Berkebutuhan Khusus.Jakarta: Departemen Pendidikan Nasional; Dirjen Pendidikan Tinggi; Direktorat Ketenagakerjaan 
Lubis.Cidartaty.(2013).Boga Dasar 1: Bahan Ajar Sekolah Menengah Kejuruan Pelaksanaan Tata Boga.Jakarta:Kemendikbud; Direktorat Pembinaan Sekolah Menengah Kejuruan

Mansur,H.R.(2015). Menciptakan Pembelajaran Efektif Melalui Apersepsi. Retrieved from LPMP Sulsel: http://www. lpmpsulsel. net/v2/index. php.

Mechling,L. C.(2008). High Tech Cooking: A Literarure Review Of Evolving Technologies For Teaching a Functional Skill. Journal of education and training in developmental disabilities, 43 (4), 474-485 Retreived From http://daddcec. org/Portals/0/CEC/Autism_Disabilities/

Research/Publications/Education Training Development Disabilities/2008v43 Journals/ ETDD_200812v43n4p474-485_High_Tech Cooking_A_Literature Review_Evolving Technologies.pdf

Mudjito, A. K., \& Harizal, E. (2012). Pendidikan Inklusif. Jakarta: Baduose Media Jakarta.

Muthohharoh,E.(2013).Upaya Meningkatkan Kemampuan Motorik Halus Melalui Kegiatan Memasak (Cooking Class) Pada Anak TK Plus Tunas Bangsa Kelompok B kecamatan Sooko Mojokerto.Jurnal Paud Teratai, 2(1): 1-16 Retrieved from http://jurnalmahasiswa.unesa. ac.id/index.php/paud-teratai/article/view/901

Persada,N.M.,Pramono,S.E.,Murwatiningsih.(2017). Pelibatan Orangtua Pada Anak di SD Sains Islam Al Farabi Sumber Cirebon.Journal of Educational Management,6(2),100-108. Retrieved from https://journal.unnes.ac.id/sju/index.php/eduman/ article/view/22774

Sari, N. W., \& Samawi, A. (2014). Pengaruh Penggunaan Media Animasi Terhadap Hasil Belajar Ipa Siswa Slow Learner. Jurnal Penelitian dan Pengembangan Pendidikan Luar Biasa, 1(2), 140-144. Jurnal P3LB,1 (2),112-119. Retrieved from http://journal2.um.ac.id/index.php/jppplb/ article/view/4315/2380
Sudarsini.(2017).Bina Diri Bina Gerak. Malang: Gunung Samudera

Sudjana,Nana.(2013).Dasar-Dasar Proses Belajar Mengajar.Bandung:Sinar Baru Algesindo

Sulistiowati,Eni.(2014).Peningkatan Kemampuan Penalaran Mata Uang Siswa Tunagrahita Praktik Jual Beli Pada Pembelajaran Siswa Vokasional Tata Boga Bagi Peserta Didik.Jurnal P3LB,1 (2),112-119. Retrieved from http://journal2.um.ac. id/index.php/ jppplb/article/view/4310/2375

Sutirman.(2013). Media \& model-model pembelajaran inovatif. Yogyakarta: Graha Ilmu

Wahyuno, E. W. E., Ruminiati, R., \& Sutrisno,S.(2014). Pengembangan Kurikulum Pendidikan Inklusif Tingkat Sekolah Dasar. Jurnal Sekolah Dasar: Kajian Teori dan Praktik Pendidikan, 23(1).7784. Retreived from http://journal.um.ac.id/index. php/jurnal-sekolah-dasar/article/view/6768

Widyoko,E.P.(2014).Evaluasi Program Pembelajaran. Yogyakarta:Pustaka Pelajar

Zain,A.R.,Ummah,U.S.,Huda,A.(2017). The Effect of Forward Chaining Method towards SelfHelp Ability for Wearing Buttoned Clothe for Students with Intellectual Disability in the Grade VII. Jurnal P3LB 4(1): 131-135. Retreived from http://journal2.um.ac.id/index.php/jppplb/article/ view/1882/1689 